\title{
Genetic variability and trait association for morphological and yield parameters of mungbean (Vigna radiata $\mathbf{L}$.)
}

\author{
Amir Sohail ${ }^{1}$, Rozina Gul ${ }^{1}$, Fakharuddin ${ }^{1},{ }^{*}$ Sheraz Ahmed ${ }^{1}$ and \\ Qamaruddin ${ }^{2}$ \\ 1. Department of Plant Breeding and Genetics, The University of Agriculture, Peshawar, Khyber Pakhtunkhwa- \\ Pakistan \\ 2. Department of Agricultural Extension Education and Communication, The University of Agriculture, Peshawar, \\ Khyber Pakhtunkhwa-Pakistan \\ *Corresponding author's email: fakharpbg@gmail.com \\ Citation \\ Amir Sohail, Rozina Gul, Fakharuddin, Sheraz Ahmed and Qamaruddin. Genetic variability and trait association for \\ morphological and yield parameters of mungbean (Vigna radiata L.). Pure and Applied Biology. Vol. 5, Issue 3, \\ pp622-631. http://dx.doi.org/10.19045/bspab.2016.50081 \\ \begin{tabular}{llll}
\hline \hline Received: 25/02/2016 & Revised: 20/0062016 & Accepted: 22/06/2016 & Online First: 24/06/2016 \\
\hline \hline
\end{tabular}
}

\section{Abstract}

Genetic variability in existing germplasm is mandatory before commencement of a successful breeding program. To estimate genetic variability and correlations among mungbean genotypes, an experiment was conducted at The University of Agriculture, Peshawar during 2014. Fourteen mungbean genotypes were sown in RCB design with three replications. Data were recorded on days to maturity (days), plant height $(\mathrm{cm})$, pod length $(\mathrm{cm})$, pods plant ${ }^{-1}\left(\right.$ no.), grains $\operatorname{pod}^{-1}(\mathrm{~g}), 1000$ grain weight $(\mathrm{g})$, biological yield $\left(\right.$ tons $\left.\mathrm{ha}^{-1}\right)$ and grain yield $\left(\right.$ tons ha $\left.{ }^{-1}\right)$. Analysis of variance showed highly significant differences $(\mathrm{P} \leq 0.01)$ among mungbean genotypes for all the studied traits. Mean value for the said traits ranged between 67-76.3, 48.7-105.7, 7.2-9.7, 15.2-22.5, 9.312.0, 42.6-55.6, 8.888-13.111 and 2.022-3.401 for days to maturity, plant height, pod length, pod plant $^{-1}$, grains pod ${ }^{-1}$, 1000 grain weight, biological yield and grain yield, respectively. Genotype Mung NM11 performed better for yield and yield associated parameters under agro-climatic conditions of Peshawar. Significant negative phenotypic correlation for grain yield was observed with pods plant ${ }^{-1}(\mathrm{r}=-0.51)$ whereas, significant positive correlation was observed with 1000 grain weight $(r=0.60)$. Based on the results of current study, genotype "Mung NM11" could be disseminated directly among growers for the commercial production of mungbean or may be included in a cultivar development program to produce transgressive segregants.

Key words: Mungbean (Vigna radiate L.); genetic variability; correlations.

\section{Introduction}

Mungbean (Vigna radiata $\mathrm{L}$.) is an important pulse crop due to its adaptation to short growth duration, low water requirement and soil fertility [1]. It is native to Indian subcontinent but it is also grown in Pakistan, China, Thailand, Philippines, Indonesia,
Burma, Bangladesh and in hot and dry regions of South Europe and Southern USA [2]. Thailand has been the world's largest mungbean exporter (approx. 30-50\%) for the last 20 years or so. Mungbean is highly praised for its rich protein content, minerals and vitamins with outstanding digestibility 
and low production of flatulence as compared to other beans [3]. In general, mungbeans contain 22-28\% protein, $60-65 \%$ carbohydrates, $1-1.5 \%$ fat and $3.5-4.5 \%$ fibers [2]. Mungbeans also contain certain essential amino acids like lysine [4]. Furthermore, it is a tropical and subtropical crop and requires a warm temperature of $30^{\circ} \mathrm{C}$ to $35^{\circ} \mathrm{C}$. It has strong tap root system with nodules to fix atmospheric nitrogen. In Pakistan, it is one of the major pulse crop and ranks second to chickpea (Cicer arietinum L.) where it is cultivated on an area of 130.9 thousand hectares with an annual production of 92.9 thousand tons, yielding $710 \mathrm{~kg}$ ha ${ }^{1}$ [5]. In Khyber Pakhtunkhwa, mungbean has covered an area of 8.6 thousand hectares with the total production of 5.4 thousand tons having an average yield of $628 \mathrm{~kg} \mathrm{ha}^{-1}$ [5].

Knowledge of genetic variability in existing germplasm is imperative in crop improvement [6]. The greater genetic variability offers more liberty to the plant breeder to produce a cultivar with broadened genetic base, such cultivars are then remain viable for a longer period of time and have the capability to resist and tolerate the biotic and abiotic stresses [7]. Direct selection for seed yield is difficult and often deceptive because of the complex nature of the trait. Hence, it is an important practice to explore the relationship among morphological and yield parameters in mungbean germplasm and then make selections based on the knowledge obtained from these correlations. This experiment was therefore, designed to investigate genetic variability and ascertain relationship among various plant traits with seed.

\section{Materials and methods}

The study was carried out at the research farms of The University of Agriculture, Peshawar during 2014. Fourteen mungbean genotypes viz., KM-1, Chasma-98, Mung NM11, Mung Chakwal-06, Mung NM-06, Mung NCM-257-2, Mung AZRI-06, Mung
97, VC-6321, VC-6369, VC-6370, VC-6368, NM-19-19, and NM-92 were planted in randomized complete block design in three replications with 4 rows measuring $4 \mathrm{~m}$ row length for each genotype. Row to row distance was maintained at $30 \mathrm{~cm}$ while plants were $10 \mathrm{~cm}$ apart in a row, respectively. Standard cultural practices including tillage, hoeing, irrigation, application of fertilizers etc. were performed during the whole crop season.

\section{Statistical analysis}

Data recorded on each trait were subjected to analysis of variance (ANOVA) and correlations coefficient using computer software SPSS v.16. Means separation for quality traits were carried out following LSD test at 5\% level of probability.

\section{Results and Discussion}

\section{Days to maturity (days)}

Plant breeder's main aim is to develop early maturing genotypes, which yields more in short period of time. Short duration varieties of mungbean can efficaciously avoid yield reducing diseases like mungbean yellow mosaic virus (MYMV) and Cercospora leaf spot (CLS). Harvesting losses can also be alleviated by developing short duration cultivars in mungbean. Therefore, early maturity is desirable in mungbeans. Highly significant differences $(\mathrm{P} \leq 0.01)$ were displayed among the genotypes for days to maturity (Table 1). Similar results were also reported by Ali et al., Begum et al. and Gul et al. [8, 9, 10]. Days to maturity among mungbean genotypes ranged from 67.0 to 76.3 (Fig. 1). Earliest maturity was exhibited by KM-1 (67.0) whereas; genotype VC-6369 took maximum days to maturity (76.3) with an average value of 72.6 days. Days to maturity had significant positive correlation with plant height $(\mathrm{r}=0.62)$ whereas, it showed non-significant association with other traits. These findings were confirmed by Derya et al. and Singh et al. [11, 12], who observed negative correlation between days to maturity 
and seed yield among mungbean genotypes.

They implied that high temperature was the

key factor responsible for longer

Table 1. Mean squares table for mungbean parameters evaluated during $\mathbf{2 0 1 4}$

\begin{tabular}{|c|c|c|c|c|}
\hline Parameters & $\begin{array}{l}\text { Replications } \\
(\mathrm{df}=2)\end{array}$ & $\begin{array}{l}\text { Genotypes } \\
(\mathrm{df}=13)\end{array}$ & $\begin{array}{l}\text { Error } \\
(d f=26)\end{array}$ & $\begin{array}{l}\mathrm{CV} \\
(\%)\end{array}$ \\
\hline Days to maturity (days) & 12.93 & $18.48^{*}$ & 6.70 & 3.57 \\
\hline Plant height $(\mathrm{cm})$ & 3.52 & $677.29 * *$ & 4.63 & 2.43 \\
\hline Pod length (cm) & 0.05 & $0.98 * *$ & 0.19 & 4.95 \\
\hline Pods plant $^{-1}$ (no.) & 2 & $24 * *$ & 1 & 5.74 \\
\hline Grains pod $^{-1}$ (no.) & 0.95 & $1.45^{* * *}$ & 0.14 & 3.30 \\
\hline 1000 GW (g) & 41.31 & $36.62 * *$ & 6.09 & 5.35 \\
\hline Biological yield (tons $\mathrm{ha}^{-1}$ ) & 4.507 & $51.790 * *$ & 6.894 & 4.88 \\
\hline Grain yield (tons ha-1) & 0.030 & 4.828 & 1.592 & 9.31 \\
\hline Harvest index (tons ha' $\left.{ }^{-1}\right)$ & 7.00 & $59.00 * *$ & 5.00 & 8.51 \\
\hline
\end{tabular}

$*, * *=$ Significant at $5 \%$ and $1 \%$ probability level, respectively

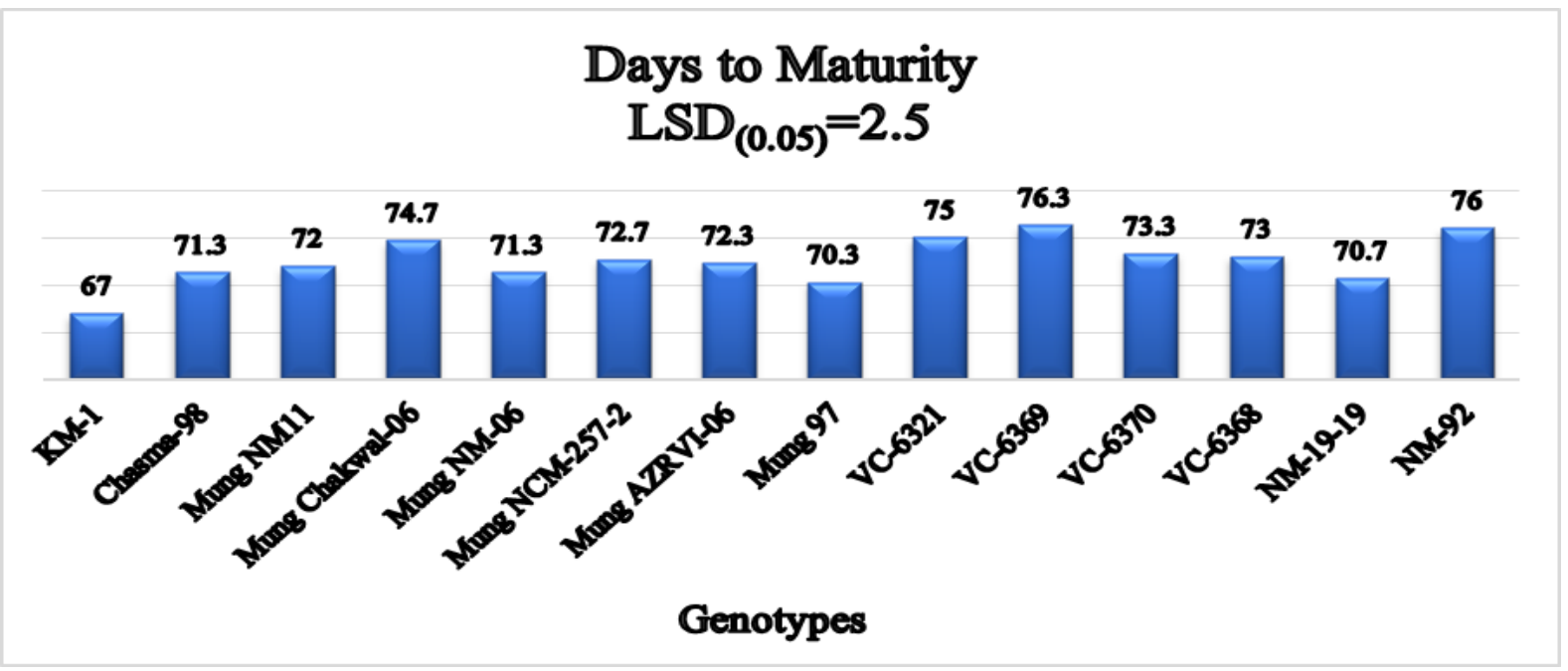

Figure 1. Mean days to maturity (days) of 14 mungbean genotypes, during 2014

\section{Plant height (cm)}

Mean squares for plant height among mungbean genotypes were significantly different (Table 1) indicating the presence of sufficient genetic variability among the tested germplasm for the said traits. Similar results were also reported by $[2,9]$. Mean values for plant height ranged from 48.7 to $105.7 \mathrm{~cm}$ (Figure 2).Genotype KM-1 produced the shortest plants while, genotype VC-6321 attained maximum plant height. Average plants were noted as $88.4 \mathrm{~cm}$. Plant height exhibited significant association with days to maturity $(r=0.62)$, whereas, non-significant with pod length $(\mathrm{r}=0.51)$, pods plant $^{-}$ ${ }^{1}(\mathrm{r}=0.45)$, grains $\operatorname{pod}^{-1}(\mathrm{r}=0.34), 1000$ grain weight $(\mathrm{r}=-0.37)$ and grain yield $(\mathrm{r}=0.21)$. Our findings are in conformity with the results of Dhuppe et al. and Pun and Villarreal [13, 14], who observed non-significant associations of plant height with other yield associated traits among mungbean genotypes. 


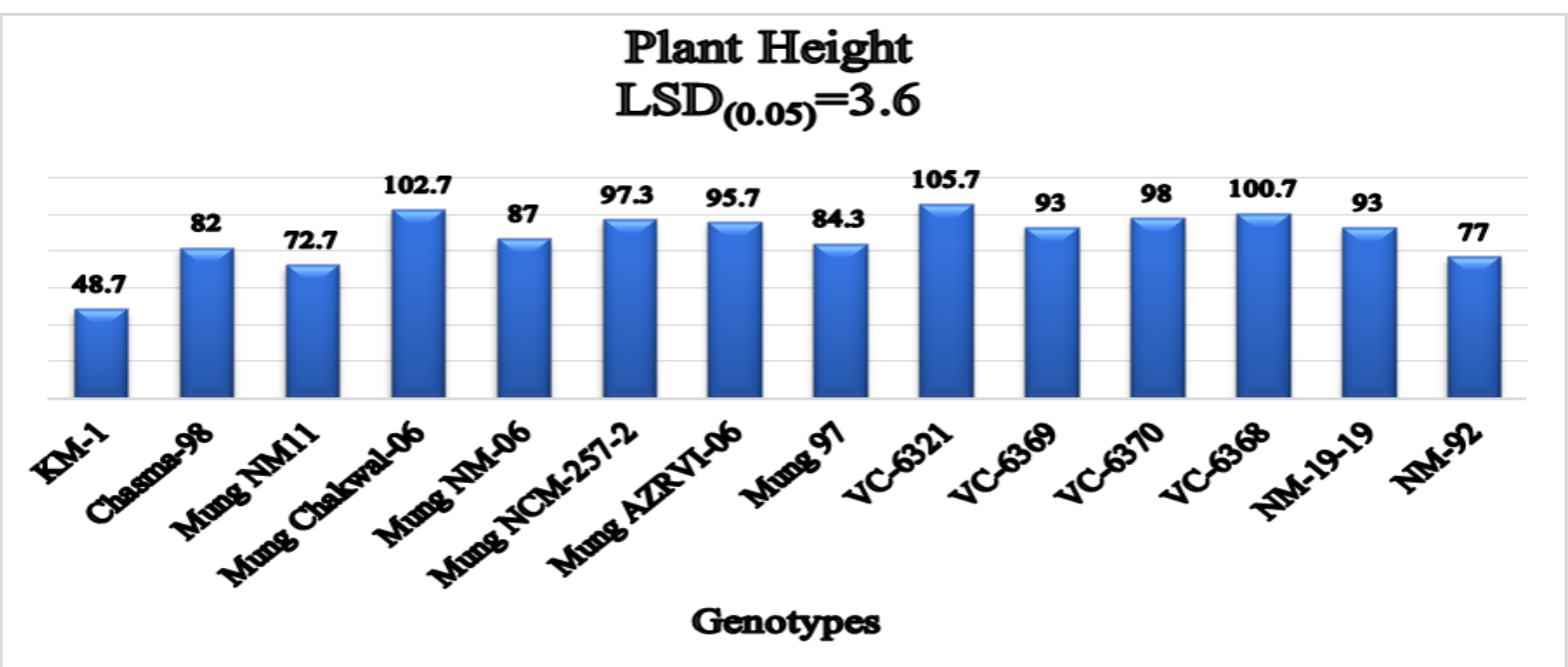

Figure 2. Mean plant height (cm) of 14 mungbean genotypes, during 2014

\section{Pod length (cm)}

Mean squares for pod length exhibited highly significant differences $\quad(\mathrm{P} \leq 0.01)$ among mungbean genotypes suggesting the existence of reasonable genetic variability among tested germplasm (Table 1). Similar findings have been reported earlier by Tabasum et al. [6]. Longer pods provide more room for seeds and as a result the dream of high productivity is more likely to be realized. Mean values for pod length among mungbean genotypes ranged from 7.2 to 9.7 $\mathrm{cm}$ (Fig. 3). Genotype KM-1 produced shortest pods and longest pods were produced by genotype Mung NM-06 with a mean value of $8.8 \mathrm{~cm}$. Pod length had nonsignificant positive correlations with days to maturity $(\mathrm{r}=0.46)$, plant height $(\mathrm{r}=0.51)$, 1000 grain weight $(\mathrm{r}=0.33)$ and grain yield $(\mathrm{r}=0.39)$ whereas, non-significant negative correlations with pods plant ${ }^{-1}(\mathrm{r}=-0.04)$ and grain $\operatorname{pod}^{-1}(r=-0.07)$ were observed. Our results are in agreement with those of Singh et al. and Dhuppe et al. [12, 15], who reported positive correlation between plant height and grain yield in wheat. However, Naidu and Satyanarayana [16] reported contradictory results to those of present finding. This vague deviation might be due to the differences in climatic conditions and genetic material.

\section{Pods plant ${ }^{-1}$ (pods)}

Pods plant ${ }^{-1}$ is an important yield contributing trait that has direct influence on the seed yield in mungbean. Analysis of variance displayed highly significant differences $(\mathrm{P} \leq 0.01)$ among the mungbean genotypes for pods plant $^{-1}$ (Table 1) suggesting the presence of sufficient variability among this set of genotypes. Similar results have been reported by Zaid $e t$ al. [2] in wheat. Mean value for Pods plant ${ }^{-1}$ among mungbean genotypes ranged from 15.2 to 22.5 (Fig. 4) where minimum pods plant $^{-1}$ were produced by VC-6368 and maximum pods plant ${ }^{-1}$ were recorded for genotype Mung NM-11 with an average value of 18.7. Current results are in line with the findings of Jalilian et al. [17], who observed significant difference among mungbean genotypes for pod plant ${ }^{-1}$. Pods plant $^{-1}$ showed significant positive correlation with grain yield, whereas, nonsignificant correlation was observed with days to maturity $(\mathrm{r}=0.19)$, plant height $(r=0.45)$, pod length $(r=-0.04)$, grains pod $^{-1}$ $(\mathrm{r}=0.27)$ and1000 grain weight $(\mathrm{r}=-0.52)$. Ali et al. [8] also reported significant correlation of pods plant ${ }^{-1}$ with yield and yield components. 


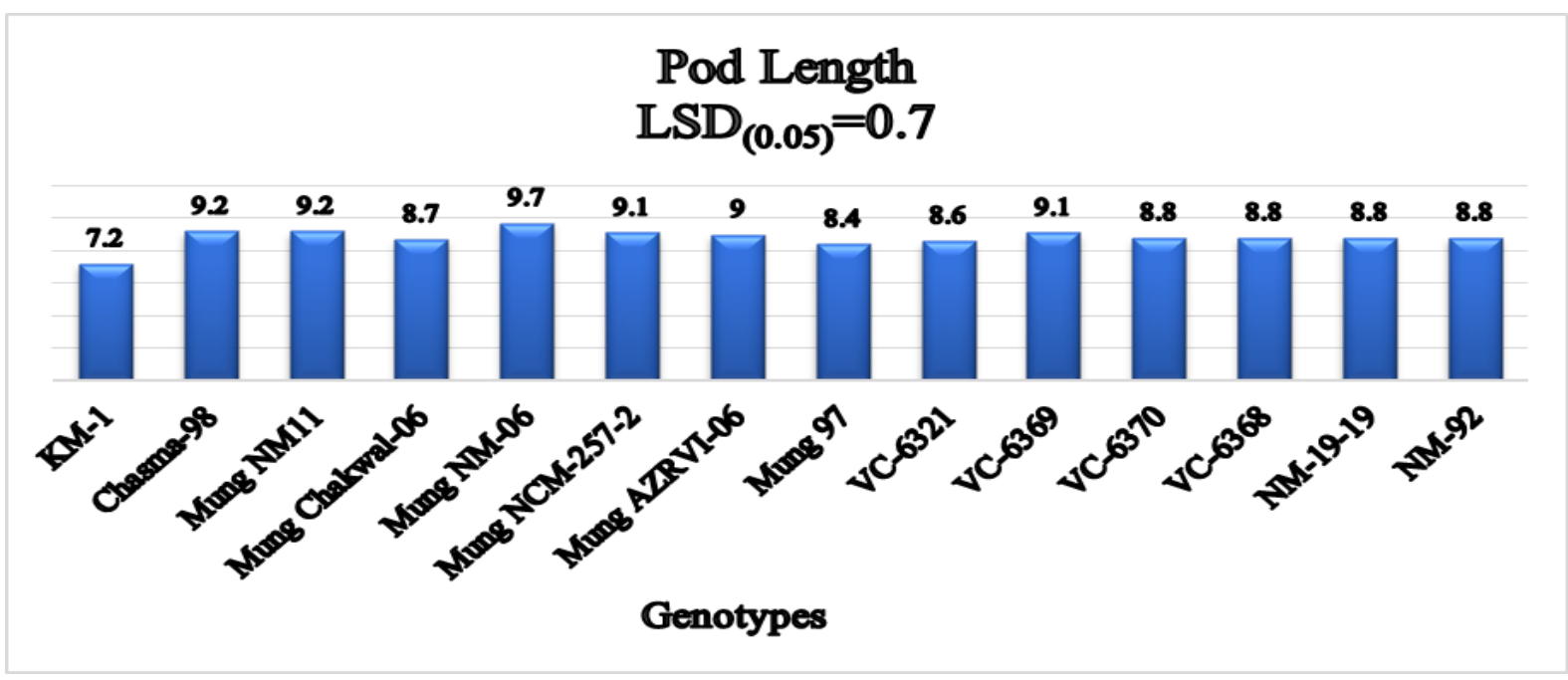

Figure 3: Mean pod length (cm) of 14 mungbean genotypes, during 2014

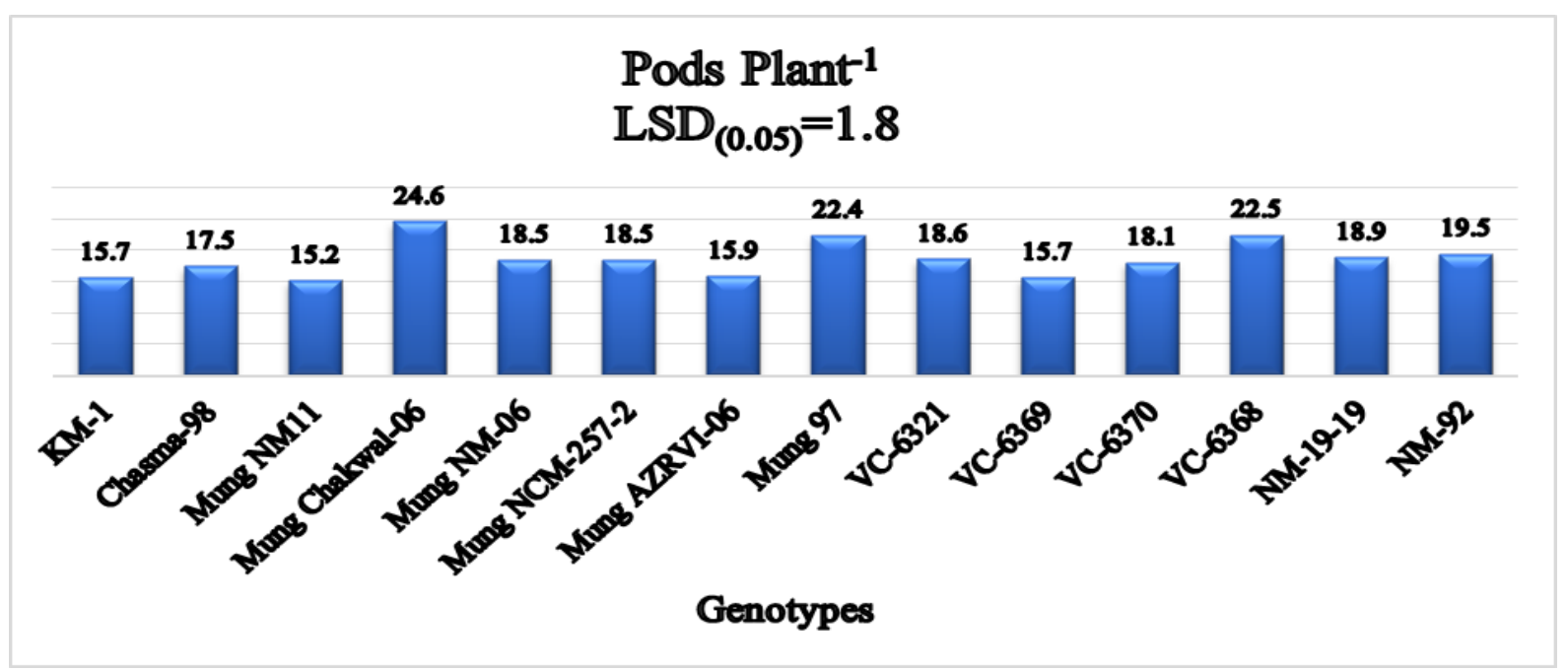

Figure 4. Mean Pods plant ${ }^{-1}$ (no.s) of 14 mungbean genotypes, during 2014

\section{Grains pod $^{-1}$ (grains)}

Mean squares values exhibited highly significant differences $(\mathrm{P} \leq 0.01)$ among the mungbean genotypes for grains pod ${ }^{-1}$ (Table 1). Similar results were also reported by Abna et al. [18]. Mean value for grains pod $^{-1}$ among mungbean genotypes ranged from 9.3 to 12.0 (Fig. 5). Minimum grains pod $^{-1}$ was recorded forNM-92 while, maximum mean value for grains $\operatorname{pod}^{-1}$ NM-19-19 with an

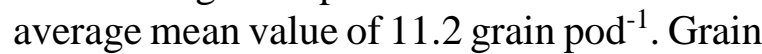
pod $^{-1}$ had non-significant correlation with days to maturity $(\mathrm{r}=-0.47)$, plant height $(\mathrm{r}=0.34)$, pod length $(\mathrm{r}=-0.07)$, pods plant ${ }^{-1}$ $(r=0.27), 1000$ grain weight $(r=-0.12)$, grain yield $(r=0.25)$ and harvest index $(r=-0.60)$. Current findings are contradictory with the results of Abna et al. [18], who observed significant association with the yield and yield related traits.

1000 grain weight $(\mathrm{g})$

Mean square values displayed highly significant differences $(\mathrm{P} \leq 0.01)$ among the genotypes for 1000 grain weight (Table 1) indicating acceptable amount of variation. Similar results were also reported earlier by Begum et al. [9]. Mean value for 1000 grain weight among mungbean genotypes ranged from 42.6 to 55.6 (Fig.6) whereas, minimum 1000 grain weight was recorded for genotype 
Mung Chakwal-06 while maximum 1000 grain weight was displayed by genotype Mung NM-11 with a mean value of $46.2 \mathrm{~g}$. 1000 grain weight had significant association with grain yield $(\mathrm{r}=0.60)$ whereas, it showed non-significant correlation with rest of the traits (Table 2).Significant correlation between 100-grain weight and seed yield was also reported by Patil and Deshmukh [19].

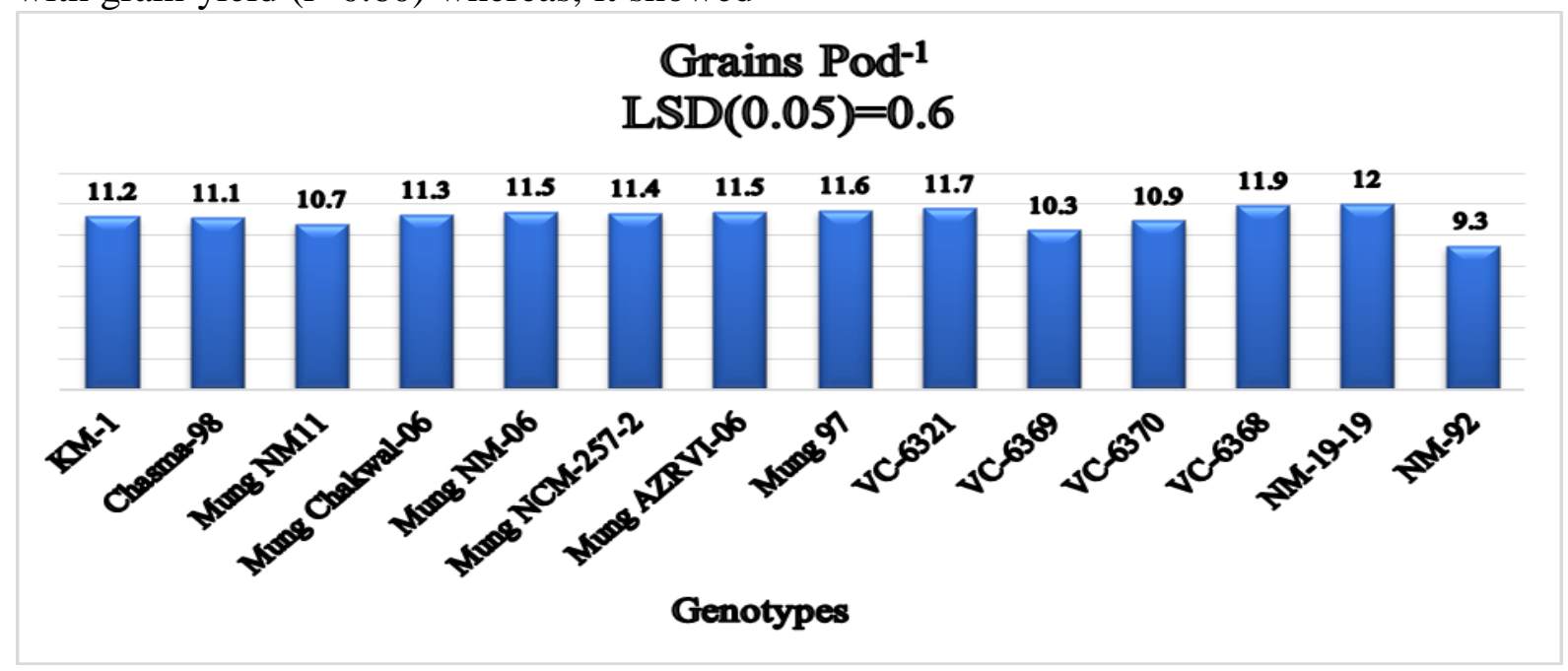

Figure 5. Mean grains pod ${ }^{-1}$ (no.s) of 14 mungbean genotypes, during 2014

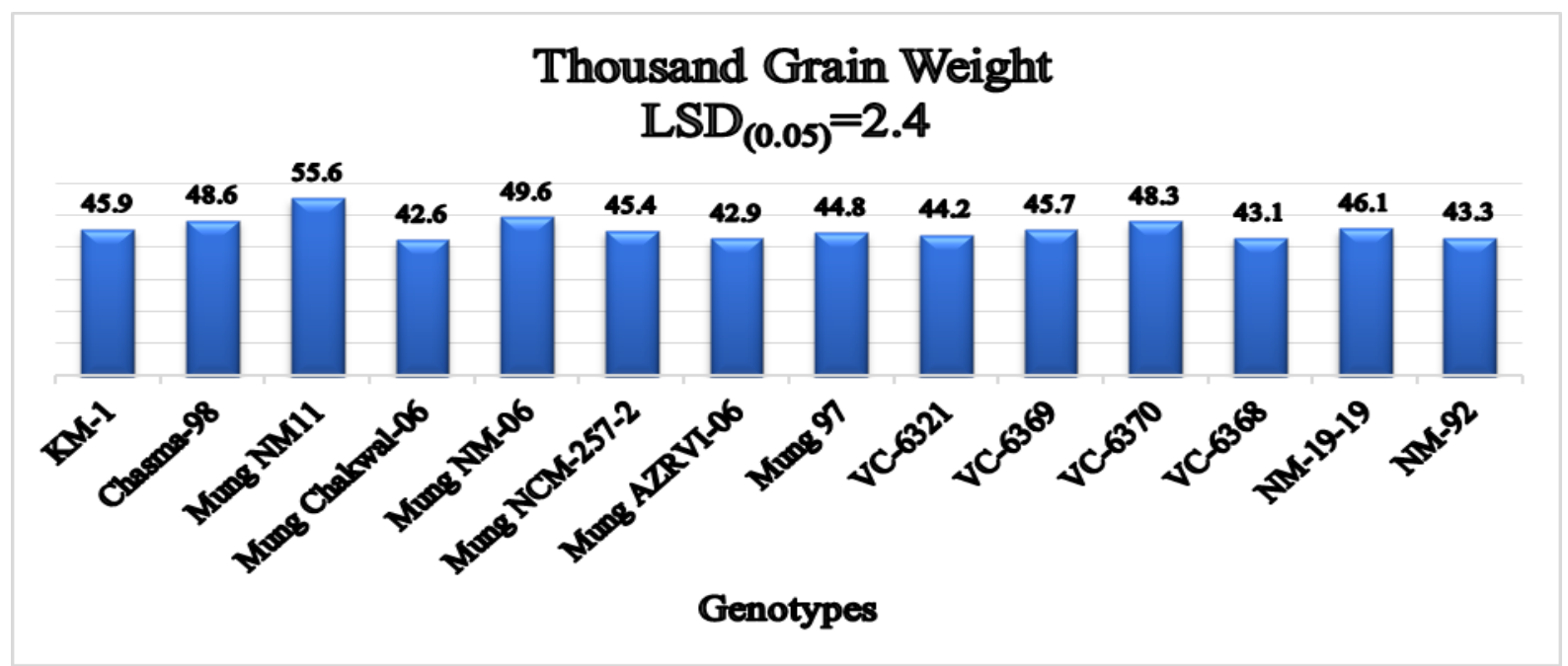

Figure 6. Mean thousand grains weight (g) of 14 mungbean genotypes, during 2014

\section{Biological yield (tons ha-1)}

Mean squares for biological yield exhibited highly significant variance $(\mathrm{P} \leq 0.01)$ among the genotypes (Table 1) indicating the presence of acceptable amount of variation. Similar results were also reported by Tiwari et al. [20]. Mean value for Biological yield among mungbean genotypes ranged from 8.888 to 13.111(Fig.7). Minimum Biological yield was recorded for genotype KM-1 $\left(8.888\right.$ tons $\left.\mathrm{ha}^{-1}\right)$ while maximum Biological yield (13.111 tons $\mathrm{ha}^{-1}$ ) was recorded for NM-92. Biological yield had significant positive correlation with days to maturity $(\mathrm{r}=0.56)$ while, non-significant association was observed by biological yield with rest of the traits. Our results are in conformity with Talebi et al. [21], who suggested that biological yield and harvest index could be 
used as base for selecting genotypes with high grain yield.

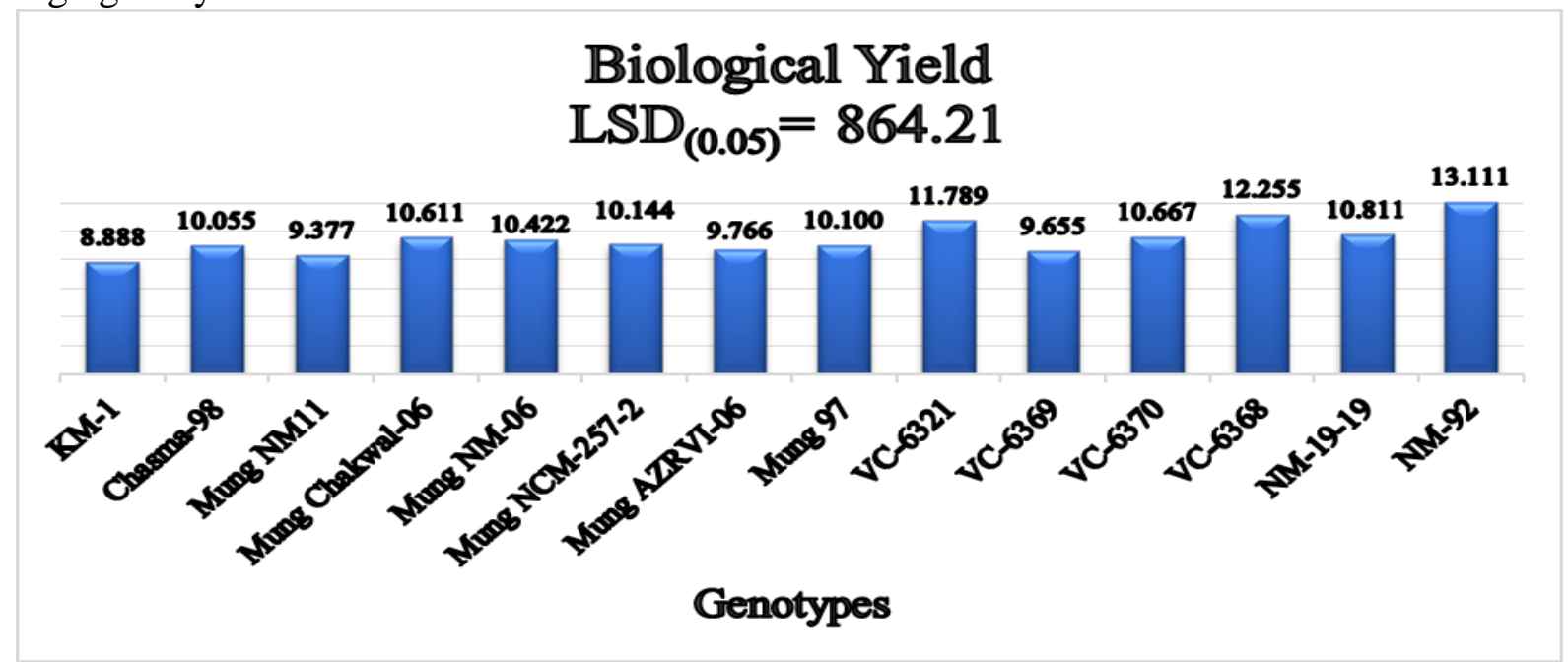

Figure 7. Mean Biological yield (tons ha' ${ }^{-1}$ ) of 14 mungbean genotypes, during 2014

Grain yield (tons ha-1)

Mean square data revealed highly significant $(\mathrm{P} \leq 0.01) \quad$ differences among mungbean genotypes for grain yield (Table 1). Our findings are in line with the results reported by Zaid et al. and Begum et al. [2,9]. Mean value for grain yield among mungbean genotypes ranged from 2.022 to 3.401 tons ha $^{-1}$ (Fig. 8) where genotype KM-1 displayed minimum grain yield and NM-92 produced maximum grain yield. Average mean value across genotypes was 2.656 tons ha $^{-1}$. Current results were similar to the earlier findings of Soltani and Hammer [22], who reported significant differences for grain yield in mungbean genotypes. Grain yield exhibited significant negative correlation with pod plant $^{-1} \quad(\mathrm{r}=-0.51) \quad$ whereas, it showed significant positive association with 1000 grain weight $(r=0.60)$ (Table 2). Similar results have been reported earlier by Dhuppe et al. and Pun and Villarreal [13, 14], who observed significant correlation among mungbean genotypes for yield and its contributing traits.

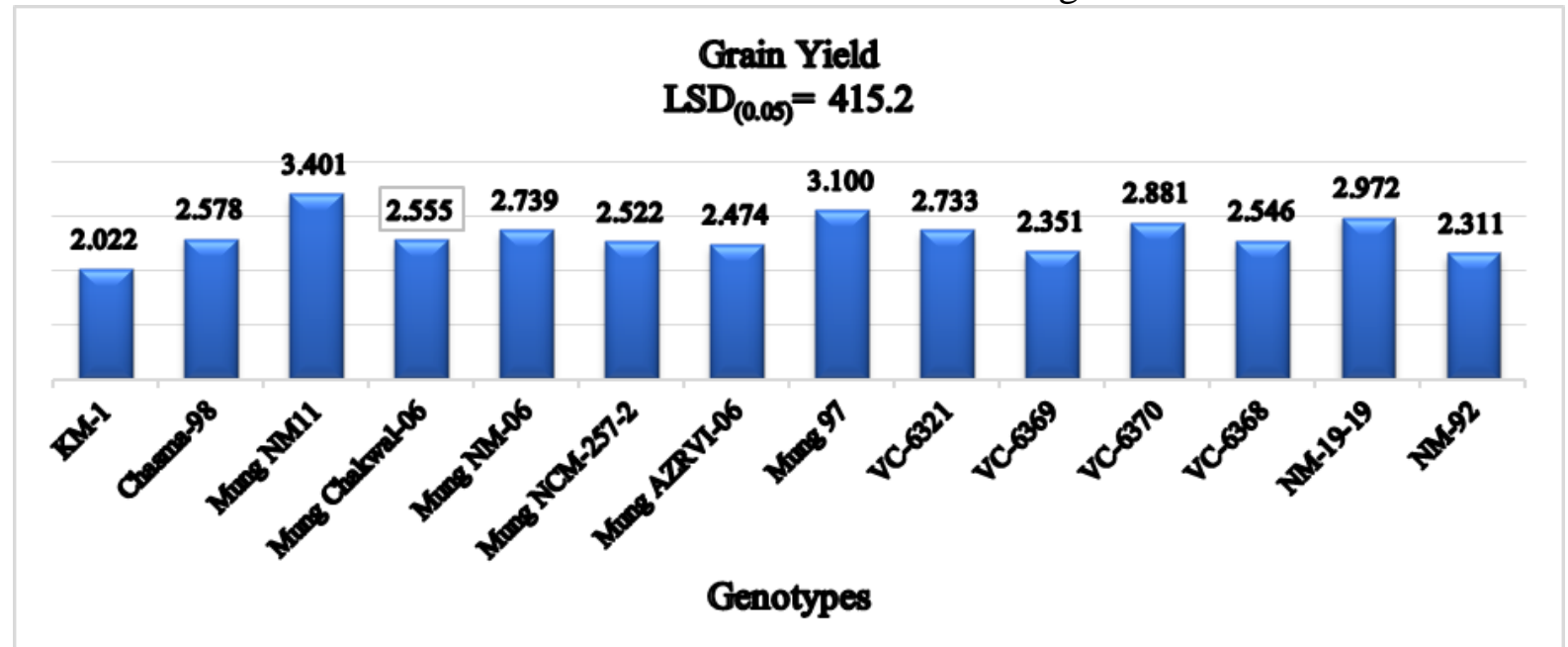

Figure 8. Mean grain yield (tons ha-1) of 14 mungbean genotypes, during 2014 
Harvest index (\%)

Analysis of variance expressed highly significant variation $(\mathrm{P} \leq 0.01)$ among mungbean genotypes for harvest index (Table 1). Our findings are in line with the earlier reported results of Tabasum et al. [6]. Mean value for harvest index among mungbean genotypes ranged from 17.7 to $36.5 \%$ (Fig.9). Minimum harvest index was recorded by genotype NM-92 whereas; maximum harvest index was recorded for genotype Mung NM11 with an average mean value of $25.5 \%$. Harvest index had significant positive correlation with 1000-grain weight $(\mathrm{r}=0.75)$ and grain yield $(\mathrm{r}=0.84)$ whereas, non-significant association was observed with rest of the traits. Our results are in conformity to the earlier findings of Tabasum et al. [6].

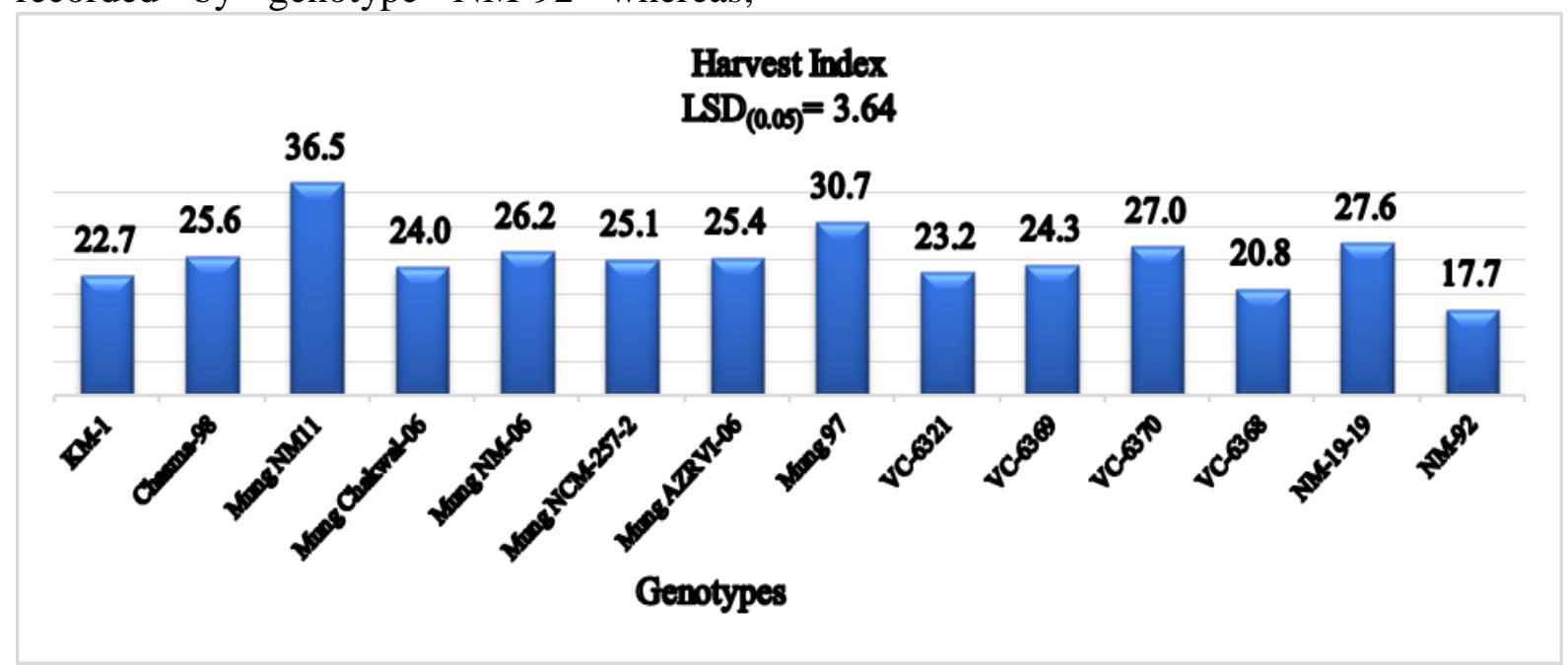

Figure 9. Mean grain yield (tons ha-1) of 14 mungbean genotypes, during 2014

Table 2. Correlation among yield and yield associated traits in Mungbean

\begin{tabular}{|c|c|c|c|c|c|c|c|c|}
\hline Traits & $\begin{array}{l}\text { Plant } \\
\text { height }\end{array}$ & $\begin{array}{l}\text { Pod } \\
\text { length }\end{array}$ & $\begin{array}{l}\text { Pods } \\
\text { plant }^{-1}\end{array}$ & $\begin{array}{l}\text { Grains } \\
\text { pod }^{-1}\end{array}$ & $\begin{array}{l}\text { 1000-grain } \\
\text { weight }\end{array}$ & $\begin{array}{l}\text { Biological } \\
\text { yield }\end{array}$ & $\begin{array}{l}\text { Grain } \\
\text { yield }\end{array}$ & $\begin{array}{l}\text { Harvest } \\
\text { index }\end{array}$ \\
\hline Days to maturity & $0.62 *$ & 0.46 & 0.19 & -0.47 & -0.28 & $0.56^{*}$ & -0.06 & -0.33 \\
\hline Plant height & & 0.51 & 0.45 & 0.34 & -0.37 & 0.41 & 0.21 & -0.12 \\
\hline Pod length & & & -0.04 & -0.07 & 0.33 & 0.15 & 0.39 & 0.23 \\
\hline Pods plant $^{-1}$ & & & & 0.27 & -0.52 & 0.01 & $0.56^{*}$ & 0.45 \\
\hline Grains pod $^{-1}$ & & & & & -0.12 & -0.19 & 0.25 & 0.23 \\
\hline 1000-grain weight & & & & & & -0.45 & $0.60 *$ & $0.75^{* *}$ \\
\hline Biological yield & & & & & & & 0.08 & -0.60 \\
\hline Grain yield & & & & & & & & $0.84 * *$ \\
\hline
\end{tabular}

\section{Conclusion and recommendations}

On the basis of current investigation following results can be concluded:

Sufficient amount of variability was recorded among genotypes for all the studied traits thus providing adequate scope for the breeder to start a cultivar development program. Genotype Mung NM11displayed maximum mean value for 1000grain weight, harvest index and grain yield, therefore could be selected as a parent in a breeding plan to achieve transgressive segregants. It can also 
be recommended for general cultivation under Peshawar conditions. Seed yield had significant positive correlation with 1000 grain weight and significant negative association was observed with pods plant $^{-1}$, therefore special attention should be given to the mentioned traits in selection process to attain high productivity.

\section{Authors' contribution}

Conceived and designed the experiments: $\mathrm{R}$ Gul, Performed the experiments: A Sohail, Analyzed the data: F Uddin, Contributed reagents/ materials/ analysis tools: Q Uddin, Wrote the paper: Fakharuddin \& S Ahmed.

\section{References}

1.Shil S \& Bandopadhyay PK (2007). Retaining seed vigor and viability of mug bean by dry Dressing treatments. J Food Legm 20: 173-75.

2. Zaid UI, Khalil IH \& Khan S (2012). Genetic variability and correlation analysis for yield Components in mungbean (Vigna radiata L.), ARPN J of Agric \& Biol Science 7(11): 1990-1997.

3. Sarwar G, Sadiq M, Saleem M \& Abbas G (2004). Selection criteria in F3 and F4 population of mungbean (Vigna radiata L.). Pakistan J Bot 36(2):297-310

4. Malik BA (1994). Grain legume. In: Crop Production (Eds: Bashir E., Bantel R.). NBF, ISB, Pak Pp. 277-328.

5. Pakistan Bureau of Statistics (2014). Ministry for Food and Agric. Govt. of Pakistan, Islamabad.

6. Tabasum A, Saleem M \& Aziz I (2010). Genetic variability, trait association and path analysis of yield and yield components in mungbean (Vigna radiata L.). Pakistan J Bot 42(6): 3915-3924.

7. Smith SE, Sing KB \& Malhotra RS (1991). Morphological and agronomic variation in North African and Arabian alfalfa. Crop Sciences 31:1150-1163.

8. Ali MA, Nawab NN, Rasool G \& Saleem M (2008). Estimates of variability and correlations for quantitative traits in mungbean (Vigna radiata L.). J Agric Social Sciences 4(4): 177-179.

9. Begum S, Noor M, Rahman HU, Hassan $\mathrm{G}$, Durrishawar, Ullah $\mathrm{H}$, Alia \& Ali F (2013). Heritability estimates and correlations among flowering and yield related traits in mungbean genotypes. British J of Applied Sciences \& Tech 3(3): 472-481.

10. Gul R, Khan H, Mairaj G, Ali S, Farhatullah \& Ikramullah (2008). Correlation study on morphological and yield parameters of Mungbean (Vigna radiata). Sarhad J Agric 24 (1):464-471.

11. Derya OY, Emin AA \& Celal Y (2006). Genetic variability, correlation and path analysis of yield, and yield components in mungbean (Vigna radiata L.). Turkish $J$ Agric 30: 183-188.

12. Singh JN, Misra MK, Chauhan GS \& Khan H (1986). Genetic association among yield and its components characters in winter season Urd (Vigna mung L.). Farm Sciences J 1:95-96.

13. Dhuppe MV, Madrap IA \& Chandankar GD (2005). Correlation and path analysis in mungbean. J Soils and Crops 15: 8489.

14. Pun \& Villarreal (1989). InterRelationship and Path Coefficient of Some Quantitative traits in mungbean Under Post Rice Growing Conditions. Philipp. J Crop Science 14(3): 91-95.

15. Khan IA (1988). Path coefficient analysis of yield attributes in mungbean (Vigna radiate L.). Legume Res 11: 41-43.

16. Naidu NV \& Satyanarayana A (1993). Heterosis for yield and its components in mungbean (Vigna radiataL.). Indian $J$ Pulses Res 6: 102-105.

17. Jalilian J, Sanavy SM \& Pour SS (2005). Effect of $\mathrm{Fe}$ and $\mathrm{Zn}$ spraying on some characteristics of mungbean using chemical and organic fertilization. $J$ of Agric Science 12 (5): 1-9. 
18. Abna F, Golam F \& Bhassu S (2012). Estimation of genetic diversity of mungbean (Vigna radiata L.). In Malaysian tropical environment. African J Microbiol Res 6(8): 1770-1775.

19. Patil HS \& Deshmukh RB (1988). Correlation and path coefficient analysis in mungbean. J Maharashtra Agric Uni 13: 183-185.

20. Tiwari A, Tiwari JK \& Mishral SP (2012). Genetic divergence analysis in mungbean (Vigna radiata L.). Intern J of
Food, Agric \& Veter Sciences 2(3): 6470.

21. Talebi R, Fayaz F \& Jelodar NAB (2007). Correlation and path coefficient analysis of yield and yield components of chickpea (Cicer arietinum L.) under dry land condition in the west of Iran. Asian J Plant Sciences 6 (7): 1151-1154.

22. Soltani A \& Hammer GL (2006). Modeling chickpea growth and development, phonological development. Field Crop Res 99:1-3. 